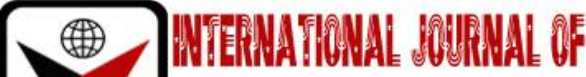

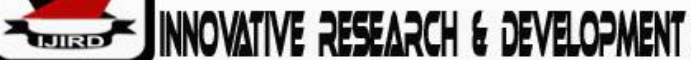

ISSN 2278 - 0211 (Online)

\section{Strategies for Women Empowerment and Poverty Reduction}

\author{
Ivy Juliana Ekuban, \\ Tutor, Foso College of Education, Assin Foso, Ghana
}

\begin{abstract}
:
The study examined the appropriate strategies that could be used to empowering women for poverty reduction in the Assin North Municipality. The quota, multi-stage and purposive sampling designs were used in selecting 196 respondents from 24 communities. Data was collected through an interview schedule and interview guide. Analysed data was presented using tables, frequencies and percentages. The strategies that could be used to empower women for poverty reduction in the Assin North Municipality included women's access to: savings and credit; work and productive resources; politics, law and justice; training; education; institutions; and healthcare. The findings of the study clearly showed that access to savings and credit; access to work and productive resources, access to politics, law and justice, access to training, access to education, access to institutions, and access to healthcare could be used as women empowerment strategies for poverty reduction in the Assin North Municipality.
\end{abstract}

Keywords: Women empowerment, poverty reduction, strategies for poverty reduction, Assin North Municipality

\section{Introduction}

Globally, poverty affects all. A country's development is based on the level of poverty of that country (European Training Foundation (ETF) (2002). Apart from its immense personal suffering, societal conflict and unsteadiness are other severe manifestations of poverty which mainly cause displacement, fractured societies and deeper poverty. Therefore, there is the need to combat poverty through appropriate means for national development since development leads to the alleviation and reduction of poverty (ETF, 2002).

Additionally, poverty is pain; it feels like a disease; it attacks a person not only materially but also morally. It eats away one's dignity and drives one into total despair. Poverty alleviation and reduction has therefore been conceived as the most important aim or by-product of development (Ahadsie\&Botchie, 2003). Poverty is the greatest challenge to all nations. This view confirms the central objective of the Millennium Development Goals (MGD) of halving of poverty by 2015 (Laderchi, Saith, \& Stewart, 2003).

It is an undisputable fact worldwide that there are more women than men but women are poorer than men. This notion led Whitehead (2003) to the conclusion that poverty has a female face. Whitehead argues that since 1999, the international Financial Institutions (IFIs) have required developing countries to formulate poverty reduction strategies aimed at reducing the enormous burden of poverty carried by poor women around in order to reduce national poverty levels. This means that the poverty level of every nation is determined by her women's population. Hence, the development of a nation is based on the development of her women. This confirms the notion that in development, women's role is irreplaceable. This view had long been encapsulated in the 1900s by one Kwegyir Aggrey in a different dimension when he made a popular statement that if you educate a man, you educate an individual, but when you educate a woman you educate a nation (Kwegyir-Aggrey, n.d).

Literature on women globally suggests that they are the most under-utilised resource for development. In the 1940s, for instance, women were only viewed as mothers and housewives. Their economic, political, and socio-cultural activities and contributions were subsequently ignored in the development process. Development theorists and planners saw men as key agents and actors at the centre of development. Women, as it has been known worldwide, bear almost all responsibility for meeting basic needs of the family but are systematically denied the resources, information and freedom of action they need to fulfil this responsibility (The Hunger Project, 1987).

It has been observed that empowering women serves as a sure prerequisite for poverty reduction. The economic, social, cultural and political status of women in society has been identified as a major determinant of the poverty status of a country. Recognition of their role and empowering them is critical to poverty reduction at the household level and national development. Women empowerment is essential for economic development, growth and poverty reduction, not only because of the income it generates, but also it helps to break the vicious cycle of poverty (World Bank Report 1995). 
In terms of strategies, many governments and women's rights advocate organisations like the United Nations Development Funds for Women (UNIFEM), National Council on Women and Development (NCWD), The World Bank, have made so many attempts to mitigate the suffering of women. Many have responded by adding women's component of preexisting development programme and projects, often focusing on handicraft production, small scale income generating or home economics (Desai \& Potter, 2002).

For example, Kabeer (1994) insists on the centrality of empowerment for the struggle to achieve gender equality. Rowland (1997) brings a broader analytical perspective to the discussion on gender and empowerment. She argues that empowerment is more than participating in decision-makingbut must as well include all processes that lead people to distinguish themselves as capable and unconstrained to make decision. She recognises that empowerment is not just a gender issue, but a development issue affecting men and women. She cautions, however that empowerment is a process but not an end product, neither easily defined nor measured. At the same time, Rowland (1997, p. 129-30) believes that: There is a core to the empowerment process...which consists of increases in self-confidence and self esteem, a sense of agency and of 'self' in a wider context, and a sense of dignity being worthy of having a right to respect from others.

From a structural perspective,poverty can be dealt with at the grassroot level, community development level and finally at the policy process level to change the systemif the problem of poverty controls the system rather than poor themselves. At the grassroots level, social movements can pressurise the vulnerable parts of the system to exert desired change. Although most studies illustrate a lack of interest in support for poor peoples' social action, Rank (2004), argues that change could be mobilised to support better jobsand a more effective system for the poor since "poverty affects us all" (pp.189-191). For instance, public pressure including unionisation can increase wages and gain employment for persons systematically excluded. Universal rights movements have had a strong impact on breaking down formal barriers, as has the woman's movement (Rank, 2004).

Changing the system within community development as a second stratey entails creating and developing alternativeinstitutions having access, openness, innovation, and a willingness to help the poor gain well being. This strategy is the cornerstone of most community development corporations which aims to provide alternative businesses, housing, schooling, and programs in addition to business strategies such as employee ownership or networks of minority or women's businesses, whilst community banks as community owned businesses provide alternative structure (Bradshaw, 2000).

Finally, change can occur through the policy process (Page \& Simmons, 2000). Job provisions, wage elevations, safety net expansions,assuring effective accessto medical care, and social insurance coordinating programsare series of social policies that can be adjusted to accomplish poverty reduction. To protectthese programs in this era of governmental entrenchment, it is undeniably clear that the poor and their advocates should be more politically mobilised. Legal changesneed to enforcecivil rights of the poor and protect minority groups.(Quigley, 2003).The literature is replete with several initiatives by women's rights advocacy groups to reduce poverty through the empowerment of women( Afotey, 2001).

There is often a yawning gap between what is perceived and what actually exists in terms of empowering women through poverty reduction as pertained in the Assin North Municipality. Available evidence indicates that, 75 percent of the informal labour-force, who are mostly peasant farmers, is women with 25 percent employed in the formal sector. Traditionally, women in the Municipality do not own land, even, if they owe their own land, their holdings tend to be smaller and less fertile than that of men. Again, the literacy rate for men (70\%) is higher than for women (30\%). There is low involvement of women in decision-making and other leadership positions (Central Regional Development Commission, CEDECOM, 2010).

\subsection{Purpose of the Study}

The purpose of the study was to examine the appropriate strategies that could be used in empowering women for poverty reduction in the Assin North Municipality.

Specifically, the study was intended to:

- $\quad$ Determine the strategies that could be used for women empowerment and poverty reduction in the Assin North Municipality.

\section{Method}

The design for the study was basically a survey design.Precisely, the descriptive survey design was employed in observing and reporting relationships between variables of the study based on the perceptions of the respondents. It was appropriate for determining and reporting opinions and views held by respondents relating to women empowerment (Best \& Khan 1993 cited in Amedahe, 2002).

The Assin North Municipal is located in the northern part of the Central Region of Ghana with Assin Foso as its capital. It is bounded on the north by Adansi South and Birim South districts, South by the Assin South District, east by AsikumaOdoben-Brakwa District, and the west by the Twifo-Hemang- Lower Denkyira District.

The study population included community members, Chiefs, and Queen Mothers and women empowerment agencies (both NGOs and government agencies) in the Assin North Municipality. A combination of quota, multi-stage and purposive sampling designs were used in selecting 191 respondents from 24 communities

The total population for the study area is 156,508. Krejcie and Morgan (as cited in Sarantakos, 2005) suggest that for a population of about 156,508, a sample size of 382 is adequate and representative. However, the study employed a sample size of 191 (50\% of 382). The choice of 191 was due to time, money and accessibility constraints and heads of all five women empowerment organisations making 196 respondents. 
The main instrument for gathering primary data was the interview schedule and interview guide.The interview schedule involved both open and close ended questions. It enabled community members chose from predetermined set of responses and as well, gave their own information that might not be captured in the predetermined choices. The instruments were put into two sections. Section A captured the characteristics of the respondents; Section B presented the strategies of women empowerment.

\subsection{Data Processing And Analysis}

Though the study was mainly qualitative, some of the data were organised for quantitative analysis. Data analyses were aided by the use of descriptive statistics (frequencies, percentages and tables).

\section{Results}

This section presents the results and discussion of the findings of the study. These have been presented under the following sub-sections: characteristics of the respondents and women empowerment strategies.

\subsection{Characteristics of the Respondents}

The level of education of the respondents showed that 29.3 percent of them had never attended school. Those with basic education formed 33.5 percent while those with secondary education accounted for 14.1 percent. It was also revealed that 23.0 percent had tertiary education. A cross-tabulation of sex and level of education also showed that females (women) formed the majority (78.6\%) of those who had never attended school. The uneducated women, however, viewed education as a powerful tool that could be used for empowering women for poverty reduction. However, the situation was different with respect to the respondents who had tertiary education as females (63.6\%) had tertiary education than their male counterpart (Table 1).

\begin{tabular}{|c|c|c|c|c|c|c|c|c|c|c|}
\hline \multicolumn{10}{|c|}{ Level of Education } \\
\hline & \multicolumn{1}{|c|}{ Never } & \multicolumn{2}{|c|}{ Basic } & \multicolumn{1}{c|}{ Secondary } & \multicolumn{2}{c|}{ Tertiary } & \multicolumn{2}{c|}{ Total } \\
\hline Sex & No. & $\%$ & No. & $\%$ & No. & $\%$ & No. & $\%$ & No. & $\%$ \\
\hline Male & 12 & 21.4 & 26 & 40.6 & 6 & 22.2 & 16 & 36.4 & 60 & 31.4 \\
\hline Female & $\mathbf{4 4}$ & $\mathbf{7 8 . 6}$ & $\mathbf{3 8}$ & $\mathbf{5 9 . 4}$ & $\mathbf{2 1}$ & $\mathbf{7 7 . 8}$ & $\mathbf{2 8}$ & $\mathbf{6 3 . 6}$ & $\mathbf{1 3 1}$ & $\mathbf{6 8 . 6}$ \\
\hline Total & 56 & 100.0 & 64 & 100.0 & 27 & 100.0 & 44 & 100.0 & 191 & 100.0 \\
\hline
\end{tabular}

Table 1: Sex and Level of Education of the Respondents

A cross tabulation of the level of education and access to credit as a strategy for women empowerment was examined. The respondents were asked to show the extent of their agreement or disagreement to the use of credit as a strategy for women empowerment (Table 2).

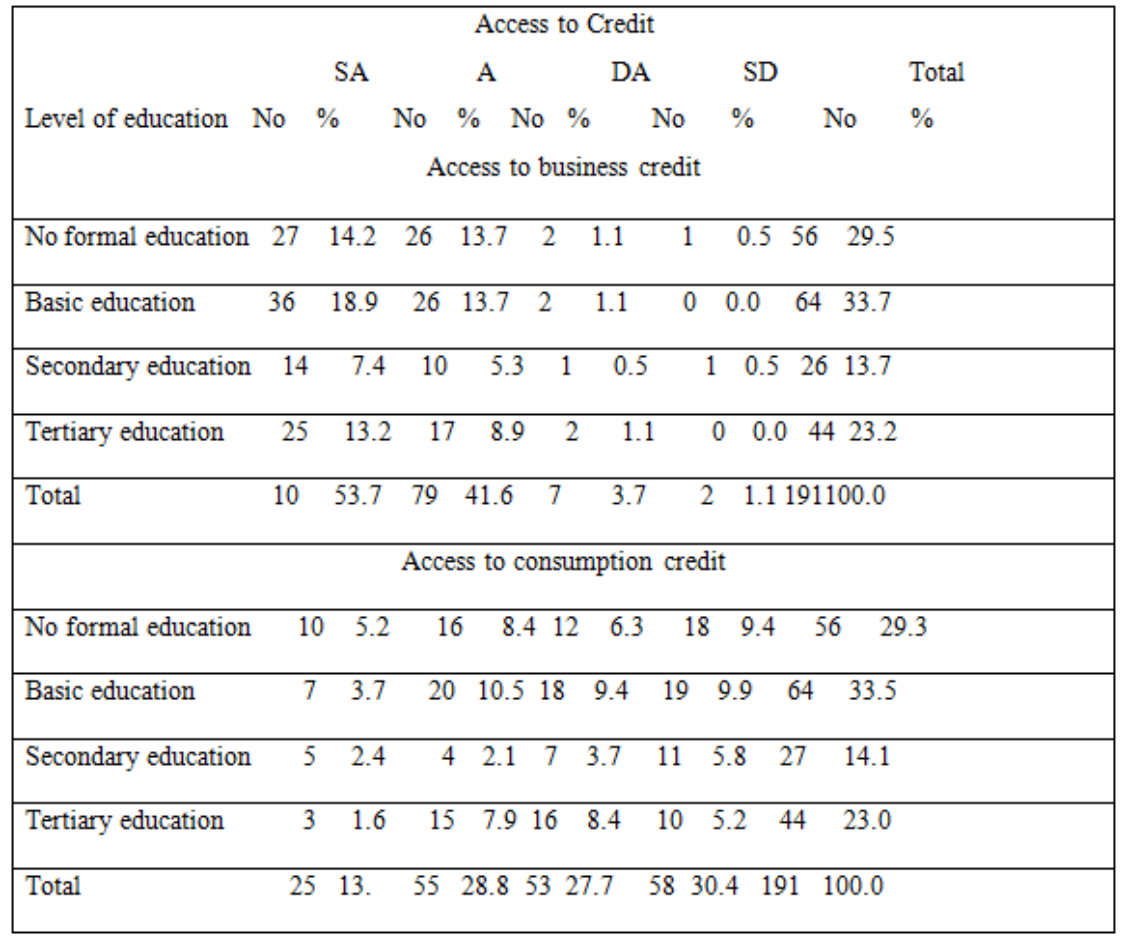

Table 2: Educational Status of Respondents and their Perception on Credit as Women Empowerment Strategy 
The results of the study, as presented in Table 6, showed that, out of the 56 respondents with no formal education, 27.9 percent were in agreement that women access to business credits could be effective for women empowerment. Among those with formal education, 32.6 percent of those with basic education, 12.7 percent of those with secondary education, and 22.1 percent of those with tertiary education respectively were in agreement that business credit to women could be used as an empowerment strategy. On access to consumption credit, however, 15.7 percent of those with no formal education were in disagreement that consumption credit could be use as an empowerment strategy among women. It could therefore be concluded that access to credit, especially business credit could be an effective strategy for women empowerment in the Assin North Municipality.

\subsection{Educational Status of Respondents and their Perception on Savings as Women Empowerment Strategy}

When the respondents were asked to show the extent of their agreement or disagreement to the use of savings as a strategy for women empowerment, all the respondents were of the agreement that women's access to savings could be use as a strategy for their empowerment (Table 3). One would have expected the educational background of the respondents to have influence their perception with those with higher education supporting savings as an empowerment strategy than those with lower or no formal education. However, as observed in Table 3, even though all the respondents supported the use of savings as women empowerment strategy, the support of those with no formal education (29.5\%) was higher than those with secondary education (14.2\%) and tertiary education (22.6\%). Those with basic education $(33.7 \%)$ were identified to have favoured the use of savings as an empowerment strategy within the Municipality.

It could therefore be concluded that access to savings, irrespective of the educational background of the beneficiary, could be an effective strategy for women empowerment in the Assin North Municipality.

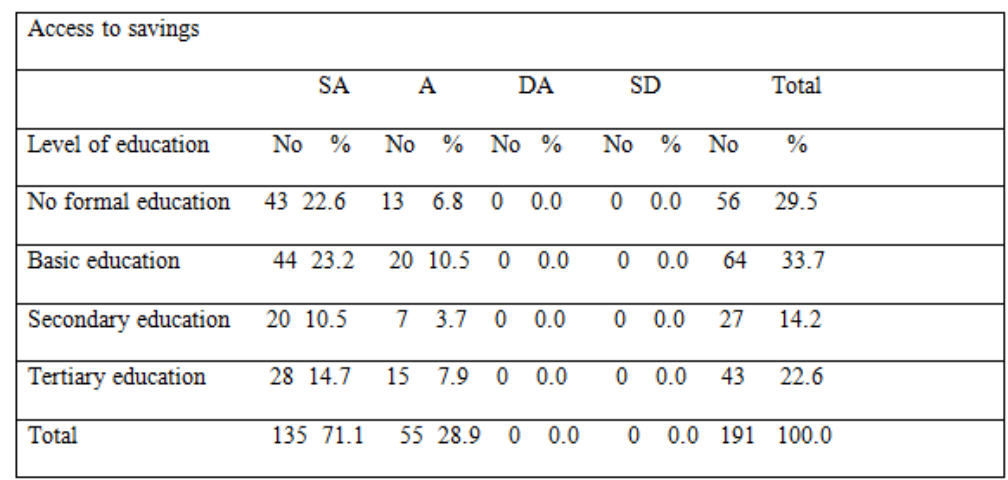

Table 3: Educational Status of Respondents and their Perception on Savings as Women Empowerment Strategy

When the occupation of community members was investigated, they identified themselves as unemployed, farmers, traders, businessmen and women, civil servants, fishermen, seamstress and hairdressers, and as baby-sitters. As shown in Table 4, majority (86.4\%) of community members were employed. The women were of the view that their access to wage employment (economic empowerment) had improved their household income and had lowered their poverty situations. The results of the study, thus, support Kabeer's (2001) observation that women employees can sometimes shift the balance of power in the family by altering the balance of power between the genders. The results also support women access to work as an empowerment strategy for reducing poverty among women.

\begin{tabular}{|lcc|}
\hline Occupation & Number & Percentage \\
\hline Unemployed & 26 & 13.6 \\
\hline Farming & 56 & 29.3 \\
\hline Trading/business & 39 & 19.8 \\
\hline Civil service & 47 & 24.6 \\
\hline Fishing & 8 & 4.2 \\
\hline Dressmaking/Hairdressing & 8 & 4.2 \\
\hline Baby-sitting & 7 & 3.7 \\
\hline Total & 191 & 100.0 \\
\hline
\end{tabular}

Table 4: Occupational Distribution of Community Members

The occupation of community members by sex showed no difference except for fishing, dressmaking/hairdressing and baby-sitting. For instance, both men and women had equal chance (4.2\%) of fishing. This was due to the fact that for 
most of these respondents, though fishing was reserved for men, women too had a role to play especially in its marketing and preservation. Women also dominated dressmaking/hairdressing and baby-sitting (Table 5).

This could explain the fact that females have traditionally been socialised to play some vital roles like baby-sitting as well as dress and hair making. It also supports the generally held view of men that dressmaking, hairdressing and baby-sitting constitute woman's work.

\begin{tabular}{|c|c|c|c|c|c|}
\hline \multirow[b]{2}{*}{ Occupation } & Male & \multicolumn{2}{|r|}{ Female } & \multicolumn{2}{|r|}{ Total } \\
\hline & No. $\%$ & No. & $\%$ & No & $\%$ \\
\hline Farming & $\begin{array}{ll}13 & 27.6\end{array}$ & 43 & 36.4 & 56 & 34.0 \\
\hline Trading & $\begin{array}{ll}6 & 12.8 \\
\end{array}$ & 20 & 17.0 & 26 & 15.6 \\
\hline Businessman/woman & 6.4 & 10 & 8.5 & 13 & 7.9 \\
\hline Civil service & $\begin{array}{ll}21 & 44.7\end{array}$ & 26 & 22.0 & 47 & 28.5 \\
\hline Fishing & 8.5 & 4 & 3.4 & 8 & 4.8 \\
\hline Dressmaking/hairdressing & 0.0 & 8 & 6.8 & 8 & 4.8 \\
\hline Baby-sitting & 0.0 & 7 & 5.9 & 7 & 4.2 \\
\hline Total & $47 \quad 100.0$ & 118 & 100.0 & $165^{*}$ & 100.0 \\
\hline
\end{tabular}

Table 5: Occupation of Cömmunity Members by Sex

* Less than the number of respondents because of non-response

A cross-tabulation of occupation and women's access to training as an empowerment strategy (Table 6) revealed that, out of the 165 respondents, 83.1 percent of those employed agreed that women's access to vocational training could contribute to their empowerment. Also, 14.2 percent of the unemployed agreed that access to vocational training could effectively contribute to women empowerment. On access to entrepreneurial training, 14.1 percent of the unemployed supported the use of entrepreneurial training as a strategy for women empowerment. Their views were also supported by those in employment as they indicated their agreement to women's access to entrepreneurial training in their empowerment process.

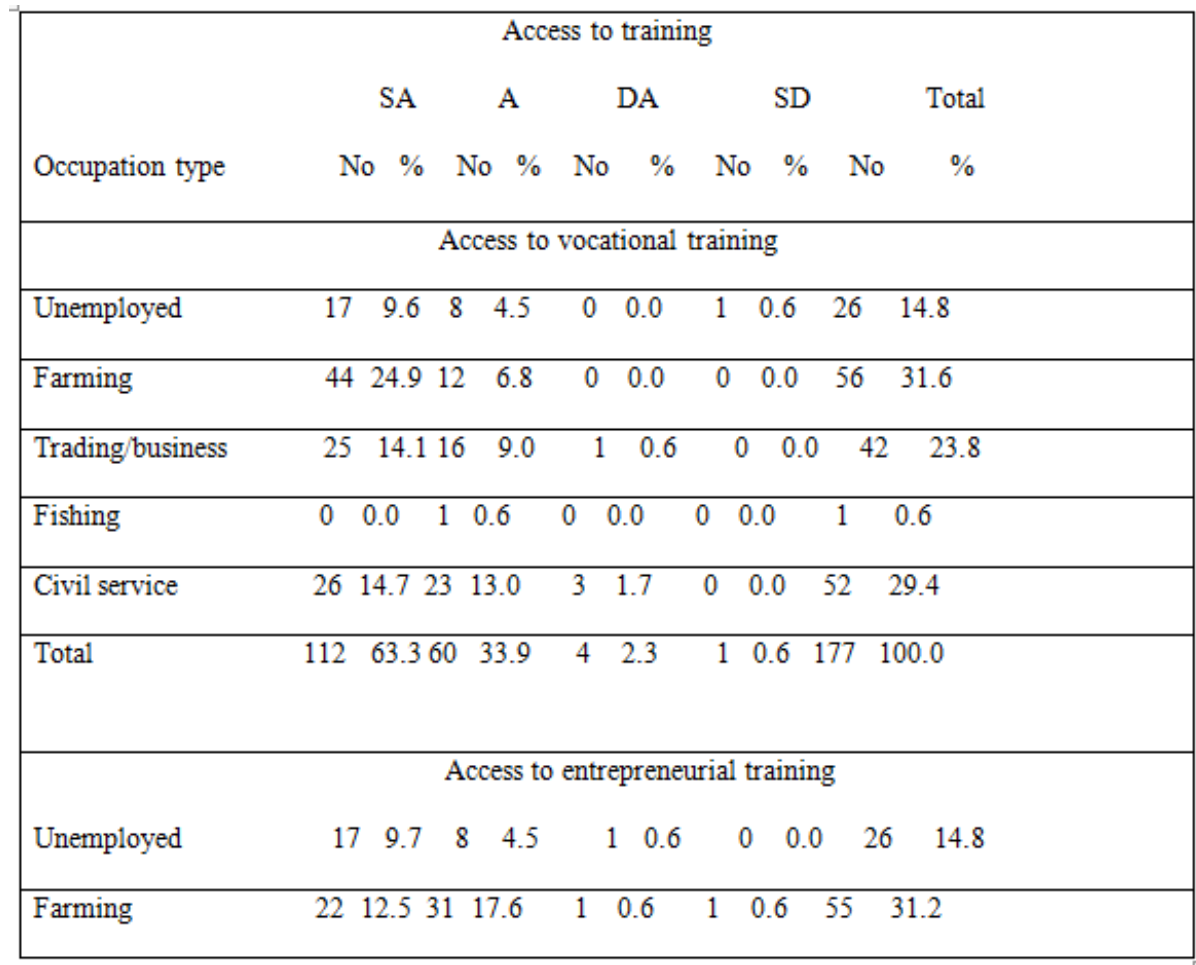




\begin{tabular}{|c|c|c|c|}
\hline Trading/business & $\begin{array}{llll}21 & 11.9 & 16 & 9.1\end{array}$ & $\begin{array}{ll}4 & 2.3\end{array}$ & $\begin{array}{llll}1 & 0.6 & 42 & 23.9\end{array}$ \\
\hline Fishing & $\begin{array}{llll}0 & 0.0 & 1 & 0.6\end{array}$ & $0 \quad 0.0$ & $\begin{array}{llll}0 & 0.0 & 1 & 0.6\end{array}$ \\
\hline Civil service & $2011.4 \quad 29 \quad 16.5$ & $\begin{array}{ll}3 & 1.7\end{array}$ & $\begin{array}{llll}0 & 0.0 & 52 & 29.5\end{array}$ \\
\hline Total & $\begin{array}{llll}80 & 45.5 & 85 & 48.3\end{array}$ & 95.1 & $\begin{array}{llll}1 & 1.1 & 179 & 100.0\end{array}$ \\
\hline \multicolumn{4}{|c|}{ Access to leadership training } \\
\hline Unemployed & $\begin{array}{llll}21 & 11.9 & 4 & 2.3\end{array}$ & 10.6 & $\begin{array}{llll}0 & 0.0 & 26 & 14.7\end{array}$ \\
\hline Farming & $\begin{array}{llll}36 & 20.3 & 18 & 10.2\end{array}$ & $\begin{array}{ll}2 & 1.1\end{array}$ & $\begin{array}{llll}0 & 0.0 & 56 & 31.6\end{array}$ \\
\hline Trading/business & $\begin{array}{llll}28 & 15.8 & 15 & 8.5\end{array}$ & $\begin{array}{ll}1 & 0.6\end{array}$ & $\begin{array}{llll}1 & 0.6 & 55 & 31.1\end{array}$ \\
\hline Fishing & $\begin{array}{llll}0 & 0.0 & 1 & 0.6\end{array}$ & $\begin{array}{ll}0 & 0.0\end{array}$ & 10.6 \\
\hline Civil service & $\begin{array}{llll}32 & 18.1 & 19 & 10.7\end{array}$ & $\begin{array}{ll}1 & 0.6\end{array}$ & $\begin{array}{llll}0 & 0.0 & 52 & 29.4\end{array}$ \\
\hline Total & $\begin{array}{llll}117 & 66.1 & 55 & 31.1\end{array}$ & $\begin{array}{ll}4 & 2.3\end{array}$ & $\begin{array}{llll}1 & 0.6 & 177 & 100.0\end{array}$ \\
\hline
\end{tabular}

Table 6: Occupation of Respondents and Their Perception on Access to Training as Women Empowerment Strategy

On access to leadership training as a strategy for women empowerment, 14.2 percent of those unemployed, 30.5 percent of farmers, 24.3 percent of those in trade and 28.8 percent of those in civil service reported that they were in agreement to women's access to leadership training as an instrument for empowering women for poverty reduction. Thus, all the respondents were in agreement that empowering women for poverty reduction in the Assin North Municipality could be achieved if women have access to vocational, entrepreneurial and leadership training.

\subsection{Strategies for Women Empowerment}

This section captures the strategies that could be used to empower women for poverty reduction in the Assin North municipality. These strategies have been put into the categories of education, training, savings and credit, healthcare, politics law and justice, institutions and other identified variables. Consequently, both men and women were asked to respond to which of these strategies, when made accessible to women could empower them for poverty reduction. The details are provided below.

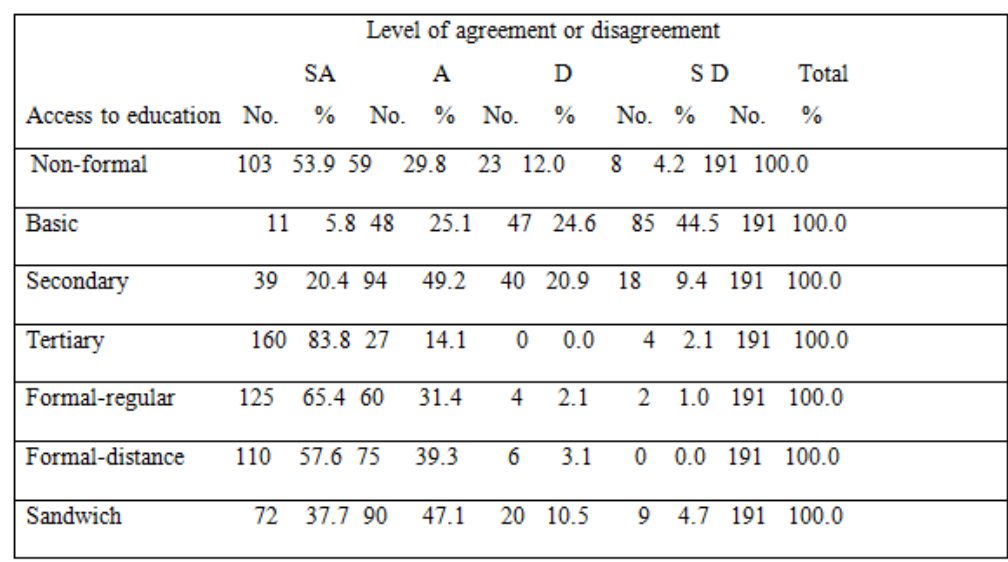

Table 7: Access to Education as Women Empowerment Strategy

\begin{tabular}{|lcccccccccc|}
\hline & \multicolumn{8}{c|}{ Level of agreement or disagreement } & & \\
& & & SA & A & D & & S D & Total \\
Access to training & No. & No. $\%$ & No. & $\%$ & No. $\%$ & No. $\%$ & \\
& & & & & & & & & & \\
\hline Vocational & 120 & 62.8 & 65 & 34.1 & 5 & 2.6 & 1 & 0.5 & 191 & 100.0 \\
\hline Entrepreneurial & 87 & 45.5 & 93 & 48.7 & 9 & 4.7 & 2 & 1.0 & 191 & 100.0 \\
\hline Leadership & 125 & 65.4 & 60 & 31.4 & 5 & 2.6 & 1 & 0.5 & 191 & 100.0 \\
\hline
\end{tabular}

Table 8: Access to Training as Women Empowerment Strategy 


\begin{tabular}{|lcccccccccc|}
\hline & \multicolumn{7}{c|}{ Level of agreement or disagreement } \\
Access to savings & SA & A & D & & S D & \multicolumn{2}{c|}{ Total } \\
and credit & No. & $\%$ & No. & $\%$ & No. & $\%$ & No. & $\%$ & No. $\%$ \\
\hline Savings & 135 & 70.7 & 56 & 29.3 & 0 & 0.0 & 0 & 0.0 & 191 & 100.0 \\
\hline Business credit & 10353.9 & 79 & 41.4 & 7 & 3.7 & 2 & 1.0 & 191 & 100.0 \\
\hline Consumption credit 25 & 13.1 & 55 & 28.8 & 53 & 27.7 & 58 & 30.4 & 191 & 100.0 \\
\hline Trade credit & 93 & 48.7 & 88 & 46.1 & 7 & 3.7 & 3 & 1.6 & 191 & 100.0 \\
\hline
\end{tabular}

Table 9: Access to Savings and Credit as Women Empowerment Strategy

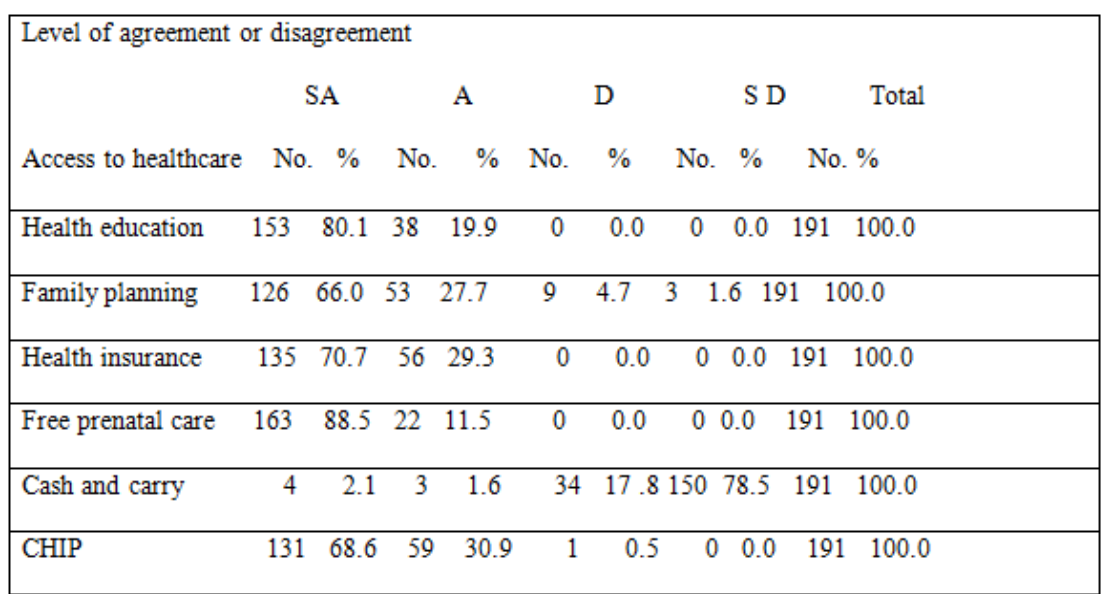

Table 10: Access to Healthcare as Women Empowerment Strategy

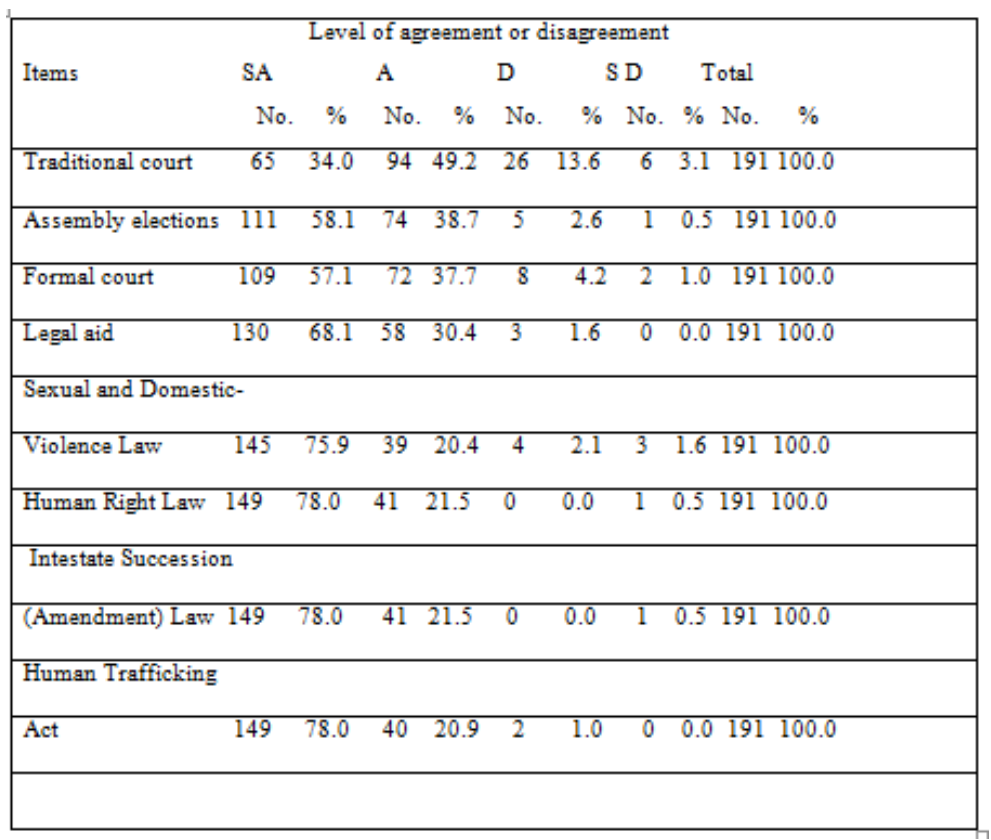

Table 11: Access to Politics, Law and Justice as Women Empowerment Strategy 


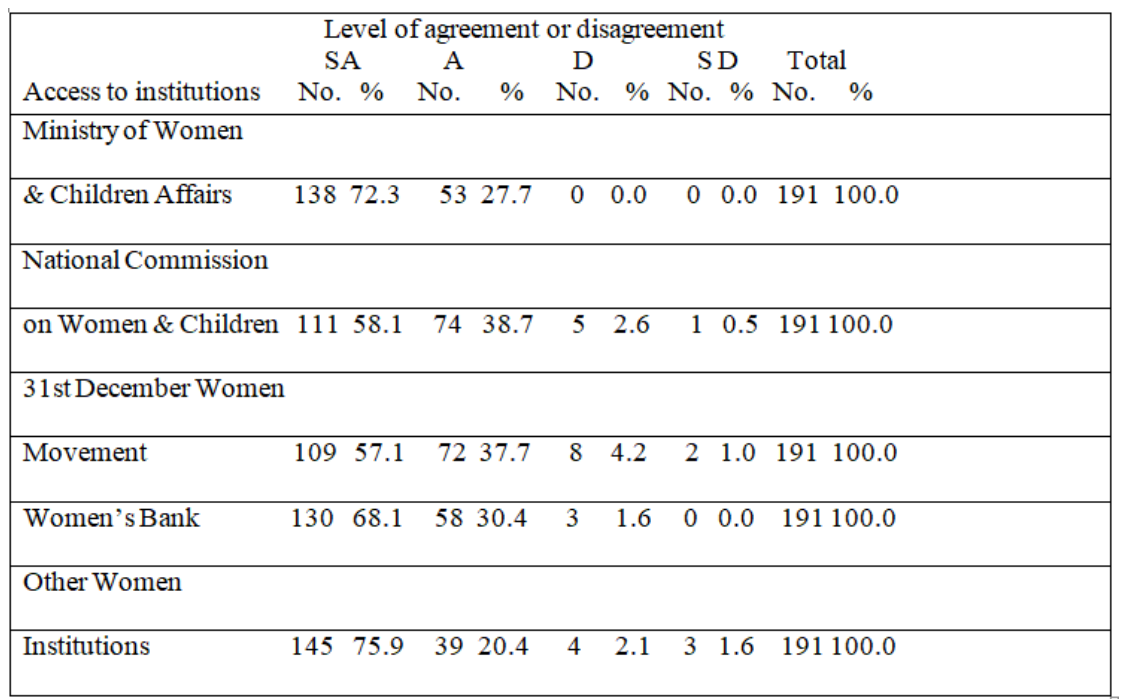

Table 12: Access to Institutions as Women Empowerment Strategy

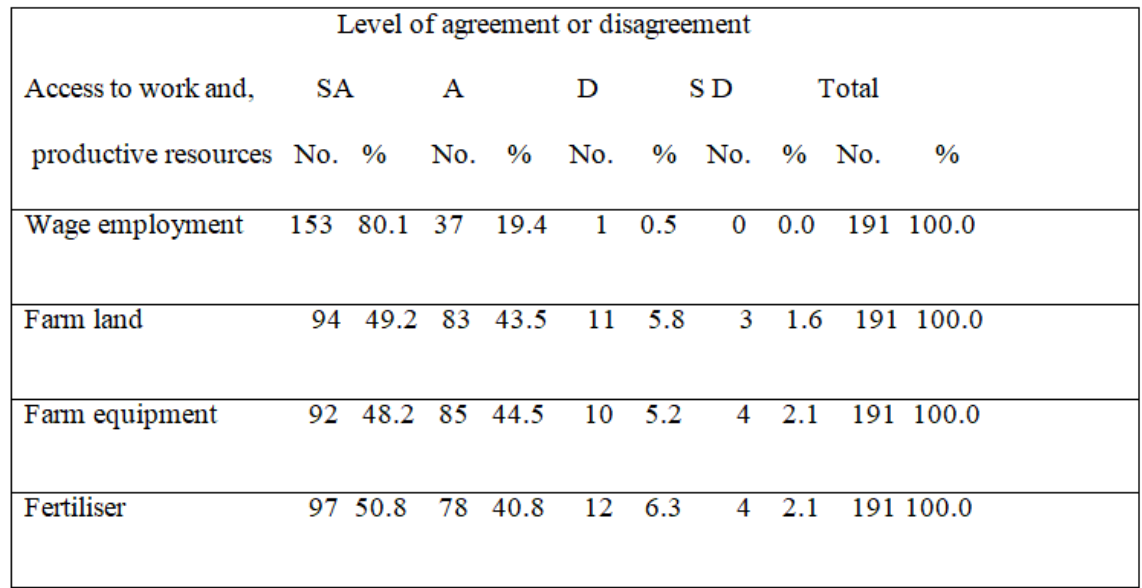

Table 13: Access to Work and Productive Resources as Women Empowerment Strategy

\section{Discussions}

\subsection{Access to Education}

Access to education in the form of knowledge, skills and attitudes are essential component of women empowerment (Kabeer, 2001). In the study, majority (95.4\%) of the respondents confirmed that access to education (basic, secondary, tertiary, formal regular, formal distance, non-formal and sandwich) education could be used as a tool for empowering women and to reduce poverty. Whereas 69.6 percent confirmed women's access to secondary education and 97.4 percent for tertiary education as the most proactive way of empowering women, 69.1 percent disagreed that access to basic education alone was not enough if women were to be empowered effectively (Table 7). The respondents held the view that education impacts on women the requisite knowledge and information and as well, promotes new ideas (Kabeer, 2001). The general impression supports the widely held view of education as the most potentinstrument for the emancipation of any group of people.

\subsubsection{Access to Training}

Women's access to training often promotes their re-orientation towards their self-confidence, psychological balance and rekindles their "can do" spirit to embark on self and societal development (Kabeer, 2001). In the study, 96.8 percent of the respondents supported the idea that women access to skill training, in the form of vocational, entrepreneurial and leadership, could be used as a viable tool for women empowerment and poverty reduction. The extent of their agreement or disagreement to skill training showed that 96.9 percent supported vocational training, 94.2 percent supported entrepreneurial training and 96.8 percent supported leadership training (Table 8). Thus, it could be concluded that access to vocational, entrepreneurial and leadership training could be used as an instrument for women empowerment and poverty reduction because it would equip them with necessary knowledge, skills and capability for undertaking viable economic activity for improved living conditions.

\subsubsection{Access to Savings and Credit}

Micro-finance programmes are promoted not only as a strategy for poverty reduction but also for women empowerment (RESULT, 1997; Khandker, 2003). In the study, when the respondents were asked to confirm how women's access to savings and credit could serve as a means of reducing poverty through empowerment, majority (98.6\%) 
supported the idea. All the respondents agreed and responded in the affirmative for women's access to savings. Also, 95.4 percent and 94.8 percent of them were in agreement that women's access to business and trade credit would be imperative to their empowerment and poverty reduction with another 41.9 percent supporting women's access to consumption credit (Table 9). It would enable them undertake new economic activities and as well help them expand their trade. Women's access to business credit would also contribute to reducing the credit inequality gap between women and the male business counterparts. Thus, it could be concluded that access to savings, business, consumption and trade credit are essential components of the women empowerment process and that, if these components are effectively and efficiently mainstream into local policies of women empowerment, their beneficial impacts would strongly be realised in reducing poverty among women.

\subsubsection{Access to Healthcare}

Women's access to appropriate healthcare would enable women to cope with societal challenges and take leadership positions because it relates to both individual and collective empowerment (Mawaya, 1999). In the study, respondents were made to indicate the extent of their agreement or disagreement to the assertion that access to healthcare practices such as health education, family planning, health insurance, free medical care for pregnant women, cash and carry system and community health implementation programme would be relevant to their empowerment process. The results of the study revealed that 89.9 percent of the respondents supported women access to healthcare. The details are presented in Table 10. It is observed that, with the exception of women's access to the 'cash and carry' system of healthcare and the community health implementation program (CHIP), where the majority (96.3\%) and (99.5\%) disagreed respectively, all the respondents agreed to access to health education, health insurance and free medical care for pregnant women, with the majority (93.7\%) also supporting family planning (93.7\%).Thus, whereas there may be disagreement over the use of the cash and carry system and the CHIP, health education, health insurance, free medical care and family planning could be use as effective strategy for empowering women within the Assin North Municipality.

\subsection{Access to Politics, Law and Justice}

The role of women in politics is key governance issue because of the likely contributions of women to national development (Quaicoe-Duho, 2009). The results of the study showed that majority (97.5\%) of the respondents were in agreement that women's access to politics, law and justice could be used to empower and reduce poverty among women (Table 11). As shown in Table 11, on the issue of women's access to legal aid, 98.5 percent of the 191 respondents were in agreement women's access to legal aid could contribute to their empowerment. Another 96.3 percent of the respondents also agreed that women's access to Laws on sexual and domestic violence could contribute to their empowerment, with another 98.9 percent supporting the use of women's access to Human Trafficking Act in their empowerment Process. It could, therefore, be concluded that women's access to politics, law and justice could be used as a strategy for empowering women for poverty reduction in the Assin North Municipality.

\subsection{Access to Institutions}

Since Ghana's independence in 1957, successive governments have established institutions, enacted laws and rectified international conventions aimed at empowering women (Dolphyne, 1987).In the study, when respondents were asked to indicate whether women's access to institutions would empower them and contribute to poverty reduction, 92.9 percent supported the idea. The extent to which they agreed or disagreed to how women's access to institutions could empower them and reduce poverty is presented in Table 12. For instance, all the respondents agreed that women's access to the Ministry of Women and Children Affairs would be essential to their empowerment process. However, 3.1 percent disagreed to the assertion that women's access to National Commission on Women and Children with another 5.2 percent disagreeing to the 31st December Women Movement as a tool for women empowerment and reduce poverty among women.

\subsection{Access to Work and Productive Resources}

Although both men and women work in the farms, in some parts of Ghana, land is traditionally owned by, and passed down to, men (IFPRI, 2002). It is also asserted that women's access to productive resources such as funds, land, fertilisers and equipment would contribute to their empowerment and poverty reduction. In the study, when asked to indicate their support for women's access to work and productive resources as an empowerment tool for poverty reduction, 98.4 percent said they supported the idea.The extent to which they agreed or disagreed to women's access to wage employment, farm land, farm equipment and fertiliser in their empowerment process is detailed in Table 13. Almost all (99.5\%) of the respondents were in agreement to women's access to wage employment. Those in agreement to women's access to farm land constituted 92.7 percent whiles those in support of women's access to farm equipment accounted for 92.7 percent, with another 91.6 percent confirming that women's access to fertiliser would economically empower women and contribute to poverty reduction.

The views of community members were corroborated by five women empowerment agencies in the Municipality. The study identified the following:

- The Department of Women, under the Ministry of Women and Children Affairs (MOAC), supported women with micro-credit and small-scale processing machinery (oil palm and gari), educated women on government policies, offered sensitisation programmes and workshops on social and health issues and as well offered women with leadership training. 
- The Ministry of Food and Agriculture (MOFA) supported women with trees, farm tools (e.g. cutlasses), chemicals, fertilisers and as well offered periodic education and sensitisation programmes on best farming practices.

- World Vision (Ghana) supported women with skills in soap and oil palm (zomi) processing, rearing of sheep, goats, grass cutters, pigs and poultry farming, offered petty trading related financial management skills, health training and sensitised women on girl child education.

- The Department for non-Formal Education supported women with literacy and numeracy training with emphasis on addition, subtraction, division and multiplication. The agency also trained women on zonal basis in income generating activities such as soap making, gari and oil palm processing and also supported women with financial management skills.

- $\quad$ Oasis Foundation adopted the community action plan (CAP), a participatory approach which focused on group dissemination, trained women for leadership positions on committees such as the community child protection committee (CCPC), provided the farmer field school (FFS) which supported women with modern agriculture practices, offered the farmer business school (FBS) which helped women farmers to form co-operative to their income and expenditure, provided women with banking skills and as well assisted women with gari and soap making skills.

\section{Conclusion}

The findings of the study clearly showed that access to savings and credit; access to work and productive resources, access to politics, law and justice, access to training, access to education, access to institutions, and access to healthcare could be used as women empowerment strategies for poverty reduction in the Assin North Municipality.

\section{References}

i. Afotey, A. (2001). Rural women empowerment through training and their contribution to community development. Unpublished dissertation submitted to the CDS, Faculty of Social Sciences.

ii. Ahadsie, W., Botchie, G. (2003). Poverty reduction in Ghana. GoGs Position. Paper presented at 1997 Consultative Group (CG) Meeting. Paris.

iii. Amedahe, F. K. (2002). Notes on educational research: An Introduction. University of Cape Coast, Unpublished.

iv. Bradshaw, T. K. (2000). Complex community development projects: Collaboration, comprehensive programs and community coalitions in complex society. Community Development Journal, 35 (2), 133-145.

v. Central Regional Development Commission (EDECOM) (2010). Assin North municipal profile. Cape Coast: CEDECOM Ltd.

vi. Desai, V. \& Potter, R. (2002). The companion to development studies. London: Arnold.

vii. Dolphyne, F. A. (1987). National Council on Women and Development an example of concerted action. In C. Oppong (ed.) Sexroles, population and development in West Africa: Policy-relatedstudies on work and demographic issues. Heinemann Portsmouth: New Hampshire.

viii. European Training Foundation (ETF) (2002). Skills development for poverty reduction. Italy: Luxembourg Publication.

ix. International Food Policy Research Institute (IFPRI) (2002). Empowering women and fighting poverty; cocoa and land rights in West Africa: Women and cocoa in Ghana. Retrieved 17th April, 2009 from: http//www.ifpri.org.

$\mathrm{x}$. Kabeer, N. (2001). Gender mainstreaming in poverty eradication and the millennium development goals: $A$ handbook for policy-makers and other stakeholders. London: Commonwealth Secretariat.

xi. Kabeer, N. (1994). Revised realities: Gender hierarchies in development thought. London: Verso.

xii. Khandker, S. (2003). Microfinance and poverty: evidence using panel data from Bangladesh. World Bank Policy Research Working Paper 2945, January, 2003.

xiii. Kwegyir-Aggrey, J. E. (n.d). If you educate a woman you educate a nation. Retrieved August 21, 2009 from: http://web.worldbank.org.

xiv. Laderchi, C. R., Saith, R. \& Stewart, F. (2003). Everyone agrees we need poverty reduction, but not what this means: does this matter? Paper presented at the WIDER conference on inequality, poverty and human well- being, Helsinki.

xv. Mawaya, A. D. G. (1999). Assessment report on political empowerment of women. Addis Ababa: Economic Commission for Africa.

xvi. Page, B. I., \& Simmons, J. R. (2000). What government can do: dealing with poverty and inequality. Chicago: University of Chicago Press.

xvii. Quaicoe-Duho, R. (2009). Financial constraint pushes women out of politics. Daily Graphic, 5 March 2009 , p. 11.

xviii. Quigley, W. P. (2003). Ending poverty as we know it. Philadelphia: Temple University Press.

xix. Rank, M. R. (2004). One nation, underprivileged. New York: Oxford University Press.

xx. RESULTS (1997). The micro-credit summit: Declaration and plan of action. World Development,24 (2), $35-53$.

xxi. Rowland, J. (1997). Questioning empowerment: Working with women in Honduras. Oxford: Oxfam Publications.

xxii. Sarantakos, S. (2005). Social research. Second edition. New York. Palgrave.

xxiii. The Hunger Project (1987). Empowering women as key change agents. New York: Columbia University Press.

xxiv. Whitehead, A. (2003). Failing women, sustaining poverty. Gender in Poverty Reduction Strategy Papers. Christian Aid.

xxv. World Bank (1995). World Bank participation source book. Washington DC: World Bank Environment Department Paper. 